回回回回回

PHILOLOGIA CLASSICA
DE PHILOLOGIS

ET PHILOLOGIA
回回回回回

VOL. 13. FASC. 2. 2018

УДК 821.161 .1

\title{
Гомер Потемкина
}

\author{
Михаил Михайлович Позднев \\ Санкт-Петербургский государственный университет, \\ Российская Федерация, Санкт-Петербург, 199034, Университетская наб., 7-9; m.pozdnev@spbu.ru
}

Для цитирования: Позднев М. М. Гомер Потемкина. Philologia Classica 2018, 13(2), 288-302. https://doi.org/10.21638/11701/spbu20.2018.209

Материалы к биографии В.П.Петрова, опубликованные И.А.Шляпкиным в 1885 г., явились ценным дополнением к мемуарам сына поэта Я.В.Петрова 1811 г. Вместе с источниками Шляпкина позднейшая критика заимствует его критические оценки, которые подчас влияют и на интерпретацию новонайденных текстов. Так, в одном из напечатанных Шляпкиным писем Потемкину Петров называет своего вельможного друга «Александром, помнящим о Гомере». Слова поэта были неверно истолкованы как «бесцеремонное» (Шляпкин) или же «шутливое» (А.Н.Егунов) сравнение себя с Гомером. Между тем очевидно, что аллюзия подразумевает любовь Потемкина к филологии. Речь о том «Гомере», которого Александр, по свидетельствам Плутарха и Страбона, читал и комментировал в персидском походе, но вместе и о том, которого будущий полководец разбирал во время своих занятий с Аристотелем. Из ошибочного толкования Шляпкин и Егунов делают верный вывод: Потемкин читал Гомера вместе с Петровым. Дружба, начавшаяся незадолго до того, как сочинитель «Оды на великолепный карусель» был приглашен в Петербург, чтобы занять место библиотекаря при кабинете, и окрепшая позднее, когда Потемкин - не без помощи Петрова достиг вершины «счастья», основывалась на общем интересе. Судя как по его стихам, так и по различным косвенным свидетельствам, ученый поэт играл роль помощника в научных занятиях фаворита. И Екатерина, и Потемкин ждали, что переводчик «Энеиды» создаст русского Гомера. Сам Петров, вероятно, на какое-то время увлекся этой идеей и даже прислал Потемкину некий «образец»: о нем также говорится в разбираемом ниже письме.

Ключевые слова: Василий Петров, русские переводы Гомера, Григорий Потемкин.

Василий Петрович Петров (1736-1799), поэт и чтеи, Екатерины, обязанный столько же славой, сколько и забвением таланту подогнать под злободневную идею

(C) St. Petersburg State University, 2018 
литературный мундир благороднейшего покроя, ${ }^{1}$ в истории русского классицизма отмечен как первый переводчик «Энеиды». ${ }^{2}$ Филологические дарования проявились, однако, и помимо труда, благодаря которому верноподданный poeta doctus, заимствуя прозорливость у автора «Антидота», вполне близоруко надеялся на бессмертие. ${ }^{3}$ Карьера будущего придворного библиотекаря начиналась в учебном заведении, которое он с блеском окончил, - Славяно-греко-латинской академии. Языки - живые, латынь, оба библейских - составляют непременный и главный его интерес. Так затем и в Петербурге, и в Англии, куда он стремился, кажется, из тех же гуманистических побуждений, ${ }^{4}$ и снова вблизи трона, на вершине успехов, и в отставке после рождения сына Язона, который, став биографом отца, засвидетельствовал, что шестидесятилетним старцем «выучился он новому греческому диалекту». ${ }^{5}$ Сквозь время слышно изумление общества языковой подготовкой Петрова. ${ }^{6}$ Саму его дворцовую лирику способны лучше оценить читатели, привычные к анализу чужой речи, лучше - древней. ${ }^{7}$ Его упрекали в неискренности, полагая, между прочим, что искренность обязана казаться прозрачной. ${ }^{8}$ Но адресатам его стихи были ясны, и, во всяком случае, по отношению к одному, особенно любимому предмету его восторгов позволительно заключать о правдивости чувства

1 Яркие примеры: Зорин 2004, 46-48, 54-56, в связи с «греческим проектом» и Морейской экспедицией; Проскурина 2006, 11-13, о политических аллюзиях в «Оде на великолепный карусель»; там же 168-177 et passim, о трансформации аллегорий в одах Петрова Екатерине в связи с изменениями государственных стратегий.

2 См. Фролов 1999, 104-105, но за оценками лучше обратиться к рецензенту нового издания избранных стихотворений Петрова: Скворцов 2017. Воспроизводить в своих оценках недовольство эпохи Майкова значит не осознавать необходимости определенных литературных условий, при которых в русской, да и в любой другой литературе становится возможным перевод Вергилия. Мало отметить разногласие академической критики и представителей нарождающегося литературного либерализма. В негодовании последних стоит расслышать спор о том, каким вообще должен стать перевод классики. Так, Хемницер ругает “ЭНеиду” несносного педанта Петрова», его удручает стремление переводчика и комментатора растолковать каждую мелочь (Боброва, Вацуро 1963, 334).

3 Об этом письмо Петрова в Академию наук: Сухомлинов 1885, 41-42; похвалы, о которых речь в письме, цитируются И. З. Серманом (1972, 320-321, с литературой).

${ }^{4}$ Кросс 2009, 181; 1976, 231. Он хотел отправиться за границу до приглашения ко двору (1768), надеясь «усовершенствоваться в познаниях»; деньги для этого собрали московские купцы, детей которых он учил: Петров 1811, 127. О пребывании Петрова в Лондоне, о загадочной фигуре его спутника и адресата двух стихотворных посланий Галактиона Силова см. кроме статей Кросса: Martynov 1979. Даже если Петров был отослан Екатериной для присмотра за юным Силовым (удобно умершим за границей во время или сразу после пугачевщины), то вернулся он со знанием европейских языков и готовым переводом «Потерянного рая». Кстати, заведовать книжной коллекцией Зимнего дворца он начал еще до отъезда (1772), а не «был назначен по возвращении» (Кросс, 1.с.): Екатерина в «Антидоте» (1770) называет Петрова «библиотекарем собственной библиотеки императрицы».

5 Петров 1818, 135-138.

${ }^{6}$ Ср. оценку М.Н. Муравьева: «Это тот из наших стихотворцев, который знает наибольшее число языков, ибо он читает в подлинниках Гомера, Виргилия, Мильтона, Вольтера, без сомнения, Тасса и, помнится мне, Клопштока. Во время пребывания его в московской академии учил он еврейскому языку» (цит. по: Кочеткова 1999, 427; см. также Амелин 2016, 9).

7 Евгений Болховитинов сказал, что Петровым восхищались бы, будь он переведен на другой язык, «так точно, как Кантемиром на французском языке»: Шляпкин 1885, 405.

8 Гуковский 1947, 34; Шляпкин 1885, 383; 405. Валентин Пикуль в романе «Фаворит» едва ли не единственный изобразил В. П. Петрова вполне честным - что, впрочем, не неожиданно для того времени, когда романы В. Пикуля пользовались особенным признанием. См. ниже, прим. 19 и 57. 
выше обычной. ${ }^{9}$ Одно имя чаще других связывается с именем В. П. Петрова - «имя странного Потемкина». ${ }^{10}$ Некоторые обстоятельства их дружбы, скрепляемой общим интересом, нам и хотелось бы прояснить.

Несогласие в оценках, частая причина расхождения в сведениях, равно мешает историку Потемкина и Петрова. С поправкой на масштаб: о Петрове обнаруживаются всего две независимые работы: 1) биографический очерк, «почерпнутый из записок, доставленных сыном его», ${ }^{11}$ Язоном Васильевичем (1780-1850), фармацевтом, профессором Медико-хирургической академии, директором «Медицинского» (Ботанического) сада в Петербурге, и 2) юношеская статья известного исследователя русских палеографических памятников, трудившегося на историкофилологическом факультете и Бестужевских курсах, «крестьянина-профессора» И.А.Шляпкина (1858-1918). ${ }^{12}$ Первый почтителен, второй беспощаден. «Других интересов, кроме эгоистических, у него почти не было»: Шляпкин клеймит «карманного стихотворца», цитируя из лермонтовской «Думы» об отсутствии «мысли плодовитой» и т.д. Сыновний пиетет самоочевиден; к тому же Язону достались в наследство способности отца. Автор латинских статей, английских, немецких переводов, он создал несколько од, и сама Vita полна красотами стиля и мысли. ${ }^{13}$ Труднее объяснить неприязнь историка литературы, плохо скрываемую уступительными фразами. Конечно, ученик Ореста Миллера, враждебный казенщине, ${ }^{14}$ мог сочувствовать всему написанному Белинским, чьи характеристики Петрова грубы до топорности. ${ }^{15}$ Если и так, то особенно укрепили Шляпкина в его мнении

9 М.А.Дмитриев $(1869,25)$ пишет, что стихи Петрова Потемкину «исполнены чувств искренних» и написаны не «от всего сердца, по участию дружества, а не тем торжественным тоном, который ставит поэта перед вельможей и полководцем, на расстоянии восторга и славы».

10 См., например, Иекуч 2014; Golburt 2015, 48. Точнее многих биографов охарактеризовавший Потемкина, А.С.Пушкин, по-видимому, лучше многих литературоведов понимает и Петрова, сопоставляя его с Державиным и хваля за сочувствие Мордвинову. Об этом: Амелин 2016, $21-22$.

11 См. Петров 1818, 138, примечание анонимного составителя, не замеченное авторами подробной статьи о Я.В. Петрове в РБС Н. Н. Кульбиным и В. И. С[аито?]вым.

12 Шляпкин 1885; «карманный стихотворец» - саморекомендация Петрова, найденная им в одном из писем к Екатерине и повторенная в письме к жене - возвышает его в собственных глазах, но унижает в представлении И. А. Шляпкина. Чей гнев, кажется, и здесь опередил понимание: Петров льстит себе тем, что стал удобным выразителем мысли, не всегда умевшей, особенно в русском слове, найти себе гладкий путь выражения.

13 «Профессор ботаники с душой поэта»: Шевчук 2012, 116. Увлекающую воображение подробность содержит его библиография в статье РБС: «перевел всю “Илиаду” гекзаметрами, но перевод этот остался неизданным». А. Н. Егунов об этом переводе (выполненном, возможно, до Гнедича) не сообщает. Интерес к Гомеру Петров-сын определенно воспринял по наследству (см. ниже), и в его труде, если он действительно состоялся, уцелел и будет когда-нибудь обнаружен, найдутся, надо думать, и следы работы Петрова-отца.

14 Кего образу мыслей: Шляпкин 1907; Буш 1920. В Пскове его даже привлекли за вольномыслие: Медников 2007. Не будучи демократом по своим политическим убеждениям, Илья Александрович явно производил впечатление очень самостоятельно думающего человека.

15 Влияние на Шляпкина оценок В.Г.Белинского, данных в статье первой «Сочинений Александра Пушкина» («Обозрение русской литературы от Державина до Пушкина»), подмечено А. Скворцовым (2017). Рассуждая о причинах отсутствия Петрова в «Пантеоне российских авторов» Карамзина Белинский, как бывает с гениями, вопреки себе выдает важную для понимания «карманного стихотворца» подробность: «Карамзин не хотел восстановлять против себя почитателей этого поэта, к которым принадлежали все грамотные люди». 
новонайденные материалы к биографии поэта. ${ }^{16}$ Илья Александрович известен как страстный собиратель, составивший, возможно, крупнейшую в России частную коллекцию книжных раритетов, рукописей и автографов. ${ }^{17}$ Начальный этап собирательства предшествовал этюду о Петрове. В 1881-1884 годах Шляпкин в обществе С.Д. Шереметева или на его и П.П. Вяземского средства путешествовал, приобретая раритеты для Общества древней письменности. ${ }^{18}$ Где и как попали к нему письма, давшие повод к написанию статьи, выяснять здесь не будем. Существеннее другое: находки помогают воссоздать историко-литературный портрет. Обаяние ревизионизма, опирающегося на «новые данные», к чему добавился заслуженный ученым авторитет, сделали этот портрет почти каноническим: он скопирован уже П.Н.Полевым, затем Г. А. Гуковским. ${ }^{19}$

Между тем изображение Шляпкина не лишено ошибок, причем в самых существенных пунктах. Он заключает, например, что Потемкин повлиял на приближение Петрова ко двору. Как аргумент цитируется без ссылки: «В святилище доброт введенный я тобой, / Питомец счастливый Минервы стал самой». ${ }^{20}$ Но приведенные строки - из послания Григорию Орлову 1769 года. ${ }^{21}$ Его автор выражается недвусмысленно: «вождь счастия, ты мне и мысли предводи». Вне всяких сомнений, Екатерине поэта рекомендовал соперник Потемкина. И совсем не Потемкин выступил «неким господином», который, как пишет рецензент в журнале «Смесь», «пуще всего избаловал известного нам умника, сказав, что он больше имеет способностей, нежели славный наш лирик». Выше Ломоносова возносит Петрова сама Екатерина, в той же главе «Антидота», где пророчествует о русском Вергилии. Анонимность автора никого не обманула, редактор «Смеси» знал, с кем полемизирует. ${ }^{22}$

Прежде чем вернуться к материалу Шляпкина и его оценкам, остановимся кратко на студенческой дружбе Петрова и Потемкина. Этой дружбы не случилось. Пишут, что Потемкин познакомился с Петровым в свой первый московский

16 «Сведения почерпнуты из собственноручных неизданных писем Петрова, мне принадлежащих»: Шляпкин 1885, 381, прим. 2, и далее, в той же сноске: «Письма, у нас находящиеся, вошли в эту статью целиком без всяких изменений».

17 Об этой его деятельности много написано: Бурьян 1959, Дубин 1999, Перетц 1960, Востриков, Лейбова, Лейбов 1995 и др. Основной корпус его книжного собрания (36862 ед.) сохраняется с 1918 года усилиями саратовских библиотекарей.

18 См. Шляпкин 1907.

19 Ср. Шляпкин 1885, 405; Полевой 1900, 111; Гуковский 1947, 359. Снисходительнее: Кочеткова 1999, 428-429; Алексеева 2005, 285-287 и Топоров 2007, 180. Маятник качнулся теперь в сторону апологетов; становится возможным непредвзятое понимание. Причина недовольства Петровым та же, что и Потемкиным - «духовное противостояние государства и общества»: Елисеева 2000, 24. Новиков, олицетворяющий сказанное противостояние, клеймил Петрова в «Словаре», откуда, смакуя, цитирует Белинский, приводя затем ответ Петрова из послания «К... Из Лондона», которое включает сатиру и на собственный портрет, и на весь «Словарь». Цитата пространна, на ней посвященная Петрову часть статьи (см. прим. 15) обрывается: то ли Белинский подразумевает, что придворному поэту все же присуще некое остроумие, то ли, наоборот, призывает оценить нелепость его ответа Новикову.

20 Здесь и далее текст цитируется нами по трехтомному изданию, составленному Язоном Васильевичем; приведенный отрывок: Петров 1811, Ч. 3, 43. Шляпкин $(1885,383)$ перепечатывает эти стихи с ошибкой: «в святилище добра я провожден тобой».

21 Что нетрудно было исправить такому знатоку, как Гуковский $(1947,354)$; ср. Серман 1972 , 319.

22 См. Виницкий 2017, 217. 


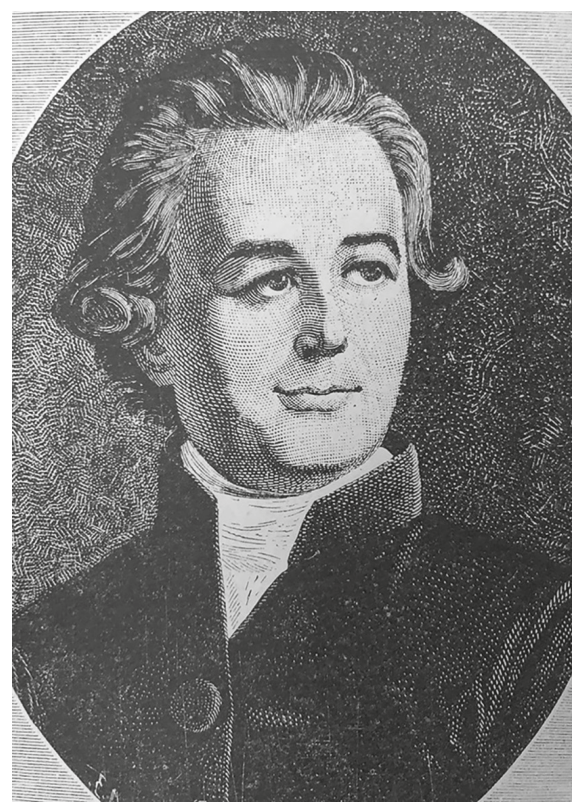

В. П. Петров.

По портрету в Академии наук (Полевой 1900, 109)

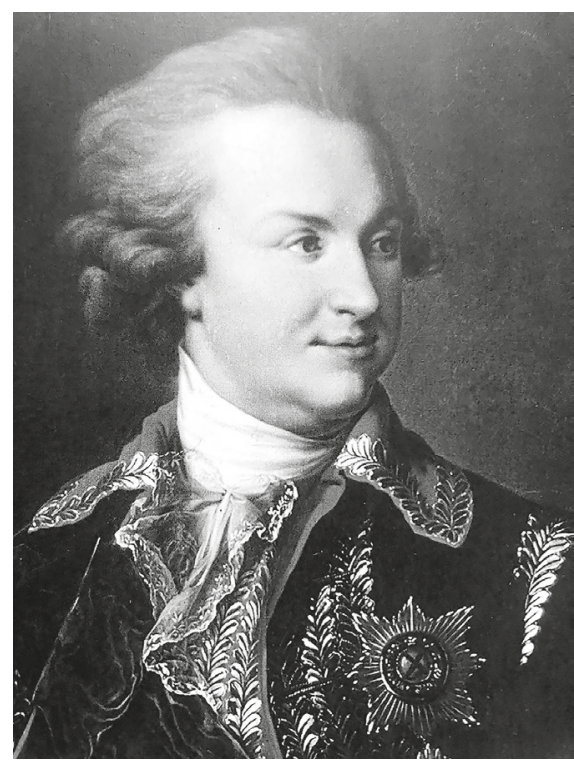

Г. А. Потемкин

Портрет неизвестного художника (Амелин 2016, 388) период, обучаясь в гимназии и университете, до отъезда в Петербург в 1760 году. ${ }^{23}$ Единственное свидетельство принадлежит М.А.Дмитриеву, поэту и переводчику Горация. Рассказы дяди легли в основу известных мемуаров, изданных через три года после смерти Михаила Александровича. Заметки о Петрове, вполне лаудативные, начинаются сообщением о том, что Ив. Ив. Дмитриев не знал его лично, «и, живучи одно время с ним в Петербурге, ни разу с ним не встречался». Следуют слухи и впечатления. «Петров был, говорят, важной наружности. Он познакомился с Потемкиным, когда оба они были еще студентами, и был до конца его жизни другом». ${ }^{24}$ Компановка характерна: важная деталь приводится как бы невзначай и оттого выглядит правдивее, особенно после указания на мужественную красоту Петрова, которой ведь славился и Потемкин. (Портреты также говорят о блестящей, совершенно в царском вкусе, общности типа). Сын, однако, указывает ясно: знакомство состоялось после «Оды на великолепный Карусель» (1766). «Князь Потемкин, бывший тогда камергером, случайно увидел сию оду и пожелал лично узнать ее сочинителя. Он посетил жилище поэта и просил его написать другую на случай составления нового уложения». ${ }^{25}$ Какие причины заставили скрыть студенческую дружбу отца с будущим фаворитом? Петров не мог не вспоминать о ней: «мы познакомились студентами» - так всегда начинают. Но Язон молчит, упоминая из ранних покровителей только Н.Н.Бантыш-Каменского. Значит, общения не было. Ведь и Дмитриев-дядя жил же в Петербурге в одно время с Петровым и вращался в литературной среде, а не познакомился. Об источнике слухов можно догадаться. В первом послании Потемкину, написанном, вероятно, на исходе Турецкой войны 1768-1774 годов, перед возвращением Потемкина в Петер-

23 Шляпкин 1885, 382; Гуковский 1947, 354; Кочеткова 1999, 425; Амелин 2016, 15 и др.

24 Дмитриев 1869, 25.

25 Петров 1818, 126. 
бург в 1773 году, Петров пишет ему как близкому другу. Они учились в Москве примерно в одно время. Нет дружбы теплее студенческой. Читатель сделал напрашивающийся, но ошибочный вывод.

Шляпкин, к чести своей, упомянул оба сообщения, хотя второе мельком. Дадим опять слово Язону Васильевичу: «Князь Потемкин, отдавая справедливость дарованиям поэта, почтил его своим дружеством. Каждый день посещал он жилище певца Карусели и в ученых беседах проводил с ним целые ночи». ${ }^{26}$ Дальше - о такой же любви к Петрову Н.В. Репнина. Камергером Потемкин сделан 22 сентября 1768 года, ${ }^{27}$ а уже 2 января 1769-го он увольняется из Комиссии об уложении, чтобы отправиться в действующую против турок армию. «Князь», конечно, анахронизм, но титул обычно получает у биографов обратную силу. Однако и «камергер» плохо сочетается с последующим известием о приготовлениях к поездке в столицу на деньги московских купцов, детей которых Петров учил, о неожиданном приглашении к царице. Словно бы событийная память Язона ослабена его русской болезнью, о которой даже РБС не забыл сказать. Репнин до февраля 1768 года был в Варшаве, где прославился «Репнинским сеймом». И зачем бы таким людям, как он, искать общества учителя, пусть и ученого? Видимо, биограф слегка смешал пласты: Потемкин и Петров сблизились в 1767 году, пока Комиссия заседала в Грановитой палате, но дружба продолжилась и осенью 1768-го, в Петербурге, когда заиконоспасский классицист уже «проводил по нескольку часов в чтении императрице лучших писателей». 28 Чем это грозило, поймем, взглянув на портрет и прочитав в позднем обращении к Ней о материнских чувствах. ${ }^{29}$ Петров сам вдохновенно свидетельствует, что встречи его с Потемкиным прервались отъездом того на войну: «Превыше чаяний взнесися, мой орел, / Ты в поле из моих объятий полетел». ${ }^{30}$

Интереснее дат - предмет их общения. Оплакивая друга, лирик вспоминает «бесед уединенных сладость, и проливанну мне от отчих взоров радость». ${ }^{31}$ Зная о мистицизме собеседника легко поверить в отвлеченный характер этих дискуссий: «Ты пренья вел со мной о промысле и роке, / О смерти, бытии и целом мира токе». Углубленность в экзистенциальные вопросы очень уместно предшествует разговору об иномирном бытии «премудрого», лучшем, разумеется, чем у скорбящих о нем друзей. Ученический пафос приходится списать на траурный контекст. Ведь ясно, что во время тех, первых встреч учителем должен был выступать Петров, а не Потемкин, который и в «счастье» стоял никак не выше блестящего чтеца. П. Ф.Кара-

26 Там же, с прим. 2: «Мать князя Григория Александровича Потемкина всегда пеняла Петрову, что он совсем завладел ее сыном». Отсюда также могли сделать вывод о знакомстве их еще в студенческие годы. Однако и цитируемое сообщение о Д. В. Потемкиной относится к новому этапу биографии Петрова, после перелома в его судьбе, произошедшем «на 30 году его возраста» (стр. 125).

27 Брикнер 1891, 18, со ссылками на источники. Следовательно, ода «На сочинение нового уложения» написана позднее, а не в 1767 г., как обычно думают (см., например, Серман 1972, 318-319; в издании 1811 г. дата отсутствует).

28 Петров 1818, 128-129.

29 Там же, 128. Цитируется «письмо об отставке» (1780 или 81 г.), в котором есть такие слова: «Я тот маленький подданной, котораго Монархиня за 30 [13? или Язон снова путает?] лет пред сим взяла из убогой хижины и посадила подле себя; как матерь, исправляя недостатки моего воспитания, соделала меня удобным к служению Ея».

30 Петров 1811, Ч.3, 49. Первое послание Потемкину, второе в сборнике посланий Петрова, следует датировать 1769 или 1770 годом.

31 «На кончину князя Григория Александровича Потемкина», там же, Ч. 2, 111. 
банов сообщает, что Потемкин добился разрешения и переписывался с Екатериной «чрез библиотекаря Петрова и Ивана Перфильевича Елагина, учителя ее русскому языку». ${ }^{32}$ Не Потемкин, если верить слышанному Карабановым "рассказу», приблизил Петрова, а, наоборот, Петров участвовал в приближении Потемкина.

Пять адресных од, три послания, и сам цитируемый трен 1791 года достаточно доказывают, что их дружеское общение, меняя тон, никогда не прерывалось. Иные указания направляют «ученые беседы» от философии к филологии. К приобретениям Шляпкина относится короткое письмо Потемкина времен первой войны с Портой: тон грустный, жалобы на молчание адресата и просьбы кланяться друзьям, «от чего у тебя шея не заболит, потому что их немного». Петрову не до писем: в 1769 г. начат «Еней», черновики поправляет сама Екатерина.

Вместо перехода у Шляпкина значится: «Потемкин не забывал Петрова и в материальном отношении». И далее: «Доказательством служит следующее письмо нашего поэта, бесиеремонно величающего себя Гомером, к Потемкину: «Милостивый государь, вчера в вечеру имел я щастие получить от Вас писание - не оцененный залог вашей к наукам любви и покровительства. Та рука, коя турков поразила, дружелюбными строками меня утешает! Признаю Великаго Александра среди звука оружий и побед, помняща о Гомере...». ${ }^{33}$ Прерываем цитату для переоценки аналогии. Меньше всего Петрову свойственна «бесцеремонность». На роль «Гомера», о котором помнит Александр, никак не годится современный Потемкину поэт. Иначе пропорция показалась бы нелепой, тогда как от мастера аллегорий, привыкшего обращаться к античности, в подобных сравнениях ожидается изысканное остроумие.

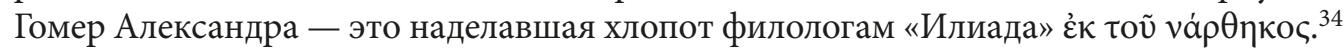
О ней повествует Плутарх: Александр «любил науку, учение и чтение (

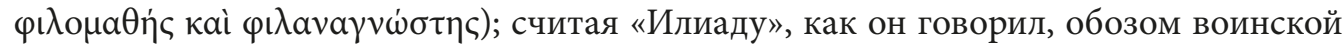

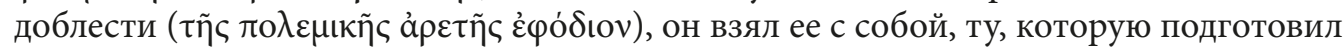
Аристотель, и которую называют “"Илиадой” из пенала». ${ }^{35} \mathrm{Ee}$, по рассказу Онесикрита, он всегда держал под подушкой вместе с кинжалом» $(A l .8,2)$.

Излишне доказывать, что оба друга читали Плутарха, пишущий, вероятно, в оригинале адресат - хотя бы в многократно переиздававшемся классическом переводе Жака Амьо (1559), которым пользовались и Шекспир, и Монтескье. ${ }^{36}$ Образ, к тому же настолько затертый, что мог быть известен и помимо перво-

32 Карабанов 2012, 59; ср. Брикнер 1891, 21; Шляпкин 1885, 388.

33 Там же, курсив наш. Письма цитируются почти подряд, на стр. 388-399; ср. прим. 36 и 40.

34 Pfeiffer 1978, 97-98.

35 Традиционный перевод «из ларца» связан с представлением о том, что в цилиндрический ящик из нартекса, обычное помещение для благовоний и лекарств, могло уместиться несколько свитков, составлявших полную «Илиаду». Страбон из своих источников знает о «критическом издании поэм Гомера, так называемом “издании из ларца", которое Александр совместно с людьми Каллисфена и Анаксарха пересмотрел и в некоторых частях снабдил комментариями, а затем поместил в роскошно украшенный ларец [пенал, нартекс], найденный им в персидской сокровищнице»

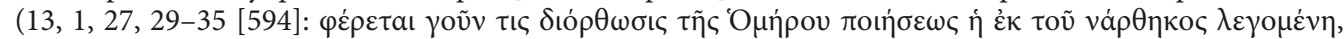

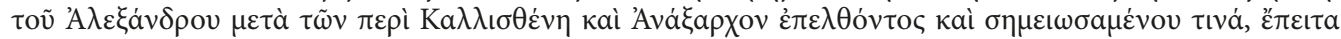

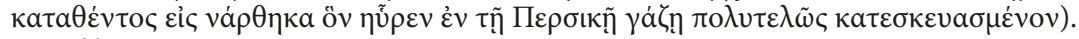

36 Soisson 2013. Русский перевод с греческого Ивана Алексеева «Плутарха Херонейского нравственных и философических сочинений часть», заказанный «Собранием, старающимся о переводе иностранных книг», вышел в 1789 году: Гаврилов 2010, 58. Около того времени (о дате см. далее подробно) написано и второе цитируемое Шляпкиным письмо. 
источников. Петров не ставит себя вровень с Гомером, но Шляпкин слишком строг к своему персонажу, потому и не заметил абсурдности схемы «Гомер благодарит Александра». Прямым путем оплошность перекочевала в монографию А.Н.Егунова о русских переводах Гомера. ${ }^{37}$ Ясно, однако, что благодарный поэт, не думая превозносить свою персону, хвалит любовь нового Александра к наукам и тем, кто их представляет. Автор видит себя не предметом изучения, но ученым и учителем. Шарм в духе времени аналогии придает известное увлечение фаворита. У Страбона Александр автор больше всех занимал князя. Из этих стихов видно, как далек Петров от фамильярности с Гомером: «Чести певца Троянской брани / Был, пишут, Александров вкус: / Как сот, Потемкина гортани / Твой стих, великий отче муз». ${ }^{38}$ Приводя цитату с искажением, превращающим оду в куплеты («приятен стих любимца муз»), Шляпкин предпосылает ей сильный тезис: «С ним Петров читал Гомера». А. Н. Егунов заключает, что Потемкин изучал греческий «под руководством» Петрова.

После и в подтверждение «Александра, помняща о Гомере» Петров прибавляет: «Так в образце моем есть одноокончательный ${ }^{39}$ [то есть, рифмованный] стих: умея поправлять строи солдат, Вы оной поправьте. Перевод сей больше будет ваш, нежели мой». Какой же, интересно, перевод?

Датировка выясняется из дальнейшего текста, в котором автор, полный признательности за щедрый подарок, стесняется даже обычного для одописца сравнения с Пиндаром: «Вы дарите мне дом. Вы тем опять сходны с Александром Великим. При разорении Фив он велел пощадить дом Пиндаров: вы мне в цветущем, где я родился, городе, на превеселом месте дарите собственный дом ваш. В том только разница, что я не Пиндар и что не могу вас так воспеть, как он Диагора, щасливаго борца, бойца и ристателя; не могу воспеть Вас, турков Перуна на земли и на море и неслыханнаго градоборца. Но я недостаток Пиндарова пыла награждаю усердием к Вам и как пчела около благовоннаго цвета жужжу, увиваясь около Вас. За безсмертия лавр почту я, ежели угожу хотя одной мыслию вашему просвещению, и простотою слога где либо двигну вашу великую душу. Я послал к вашей светлости мою оду, и думаю, вы ее уже прочитать изволили. Теперь смею послать Вам безделку, для забавы прочтите только начало и конец. К Государыне я не смел ее послать, как тово нестоющую. Она у меня напечатана давно, и ваша светлость ее первые видите. Вашей светлости милостиваго государя нижайший слуга В.П.».

В письме Петрова Потемкин - «светлость», значит, князь, повелитель Новороссии (1776). ${ }^{40}$ «Турков Перун», причем «на земле и на море», и «неслыханный гра-

37 Егунов 2001, 51: «Петров остался переводчиком Вергилия и Мильтона. В одном из своих писем к Потемкину он называл его шутливо Александром, а себя Гомером».

38 Петров 1811, Ч. 1, 191.

39 Термин восходит к Кантемиру, напечатавшему под псевдонимом «Харитон Макентин» (анаграмма его имени) в приложении к переводу «Посланий» Горация (1744) «Письмо о сложении русских стихов». В этом пособии «одноокончательными» называются стихи, в которых в противоположность «степенным» и «свободным», кроме определенного количества слогов, «всякие два стиха» должны рифмоваться. «Образец» Петрова содержал, следовательно, рифмованные попарно стихи.

40 Из соседства двух писем в публикации Шляпкина ошибочно выводилась близость их дат: Кочеткова 1999, 425-426. «Во время рус.-тур. войны 1769-1772 Потемкин, находясь в действующей армии, вел с П. дружескую переписку, из которой, в частности, известно, что он подарил П. свой дом в Москве». Но, дом, как видим, подарен в конце 1780-х. И ясно почему. Петров, живший с 1781 года в своем имении в Орловской губернии, приезжал в Москву каждую зиму заниматься в библиотеке 
доборец» сообщают бо́льшую определенность: взятие Очакова состоялось в июне 1788 г. На арке, возводимой в Царском Селе к приезду победителя, велено было начертать из триумфальной оды Петрова, той самой, вероятно, которую «прочитать изволил», и за которою по-царски отблагодарил: «Ты в плесках внидешь в храм Софии». ${ }^{41}$ Оценим аллюзию на седьмую Олимпионику, во славу многократного чемпиона Диагора Родосского, чьи прежние и нынешние победы призваны отразить сегодняшние и ранние, времен первой войны, победы Потемкина. «Дом», кста-

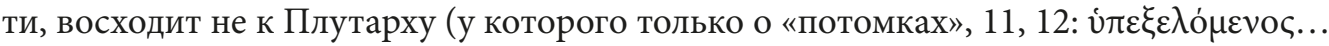

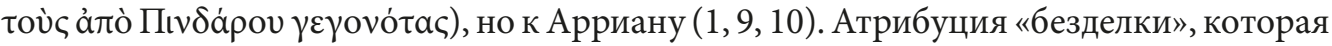
«напечатана [то есть, окончена] давно», затруднительна. Исчез и более интересный нам «перевод». Полная «Энеида» издана в 1786 году. Мильтон вышел гораздо раньше (1777), да и неизвестно, читал ли адресат по-английски. Думаем, Петров пишет именно о Гомере, предмете давних интересов Потемкина. В отзыве о первых книгах «Енея» директор Академии наук С. Г. Домашнев высказывает пожелание, «чтоб и образец Виргилиев был подарен российским письменам сим выразительным прелагателем и чтоб он в сем случае склонился на общее желание, коего один знаменитейший наук покровитель есть побуждением своим в оном ему истолкователем». ${ }^{42}$ Намеком на эти же чаяния могло восприниматься сравнение двух слепцов в послании, которое Н.М.Муравьев адресовал создателю русского Мильтона. ${ }^{43}$ Вельможный друг требовал, и в ответ на просьбы получил «образец». Вероятно, из «Илиады» раз исправить его должен «умеющий поправить строи солдат».

Внимание к Гомеру отмечается первым биографом Потемкина А.Н.Самойловым. Желая изучить историю Церкви и «еллиногрегреческий язык», которого как предмета преимущественно богословского не было в гимназическом и университетском курсе, любознательный пансионер ищет наставников. Находится «иеродиакон греческого монастыря Дорофей», от которого «не только приобрел склонность, но и самую страсть к изучению истории церковной и еллиногреческого языка». ${ }^{44}$ Любопытное дополнение к биографии Дорофея Возмуйлоса (1733-1790): прежде чем сделаться настоятелем церкви Русского посольства в Константинополе (1759), инок с Афона, обретаясь в Николо-Греческом монастыре, знакомится с необычным учеником. «Чрез наставления Дорофея мог разуметь Гомера, постигать красоты его, мог делать из оных сравнения с древними и новыми стихотворцами и отдавать ему предпочтение». Трудно понять, как церковная история сочетается с Гомером. «Государыня, - вспоминает тут же Самойлов, - во время архиерейского служения в придворной церкви призывала его к своему месту, спрашивала изъяснений о таинствах литургии и об обряде облачения архиепископского». Здесь, наоборот, полная ясность. Учебником греческого Потемкину служил часослов, других в то время не предполагалось. Вместе с аористами и наклонениями юный авва объяснял увлекшемуся богословием студенту чины и молитвы суточного круга. Усердием в общем деле один заслужил обер-прокурорский стол в Синоде, дру-

своей alma mater (Петров 1818, 135). Потемкин подарил другу дом, чтобы тому было, где остановиться.

41 Брикнер 1867, 161; Огарков 2014, 36 и др.

42 Домашнев 1779, 45.

43 Алексеев 1982. Послание Муравьева Петрову опубликовано по автографам, там есть строчки: «Слепец, другой Гомер, свергает смертны узы / Мильтон, чтоб созерцать сиянье божества».

${ }^{44}$ Самойлов 1867, 4, 591-592 с примеч. 15. 
гой - епископство в Феодосии. Но Гомер? Самойлов примешал Гомера, потому что в увлечениях Потемкина есть общее: поэмы Гомера и творения святых отцов писаны «еллиногреческим». Хотя, как мы понимаем, очень разным: умеющий прочесть одно совсем не вдруг поймет другое.

Петров учил греческий тем же способом, что и все слушатели Заиконоспасской академии: пройдя грамматические правила, сравнивал греческий богослужебный текст со славянским переводом. Учебной функцией, скорее чем филологической требовательностью русского общества XVIII века, объясняется умножение переводов одного и того же греческого или латинского текста (Цезарь, Непот, Курций Руф, Эзоп), равно как и прибавление новых, например, философов, русские издания которых осуществлял Г.А. Полетика. ${ }^{45}$ Претерпев унижение от начальства, семнадцатилетний Петров - сообщает сын - сбежал на время в Петербург. Тогда и в его биографии возникает Гомер. «Здесь нашел он приют у одного своего родственника и здесь-то ревностно принялся за творения Вергилия и Гомера». ${ }^{46}$ Причем быстро ощутил вышесказанную разницу и нехватку системы. Подходим к достижению Петрова, важному столько же для нашей темы, сколько и для русского просвещения. В 1746 году питомец Киево-Могилянской академии Василий Лащевский подготовил латиноязычный учебник греческого. Исправленный вариант с прибавлением хрестоматии издан в 1779 г. Георгием Щербатским. ${ }^{47}$ Через десять лет в Петербурге опубликована русская версия, ставшая употребительной в школьном обиходе: «Греческая грамматика, в коей синтаксис, также различные греческие диалекты и просодия из разных древних писателей выбранными правилами и примерами объяснены. Переведена студентом Васильем Петровым». ${ }^{48}$ Так заполняется пробел, который в просвещенной Европе ликвидировал Меланхтон.

В годы возвышения Потемкин продолжает штудировать язык, которому назревший еще ранее «греческий проект» придал геополитическое звучание. Одно из приобретений Шляпкина - письмо «сиятельнейшему графу» (Григорию Орлову?), писанное из армии Румянцева вскоре после Чесменской битвы тоном, содержит греческий текст знаменитого пророчества, которое, по преданию, было

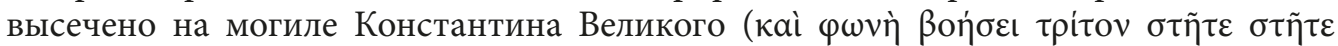

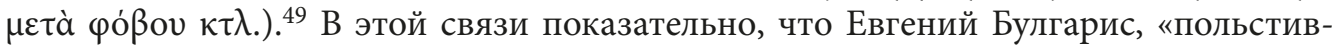
ший Потемкину переводом на греческий стихов Петрова, сочиненных в честь князя», ${ }^{50}$ становится архиепископом херсонским. Характерно, с другой стороны, внимание к многообразным попыткам создать русского Гомера. Потемкин экзаменует Кострова, поддерживает Екимова и особенно покровительствует Моисею Гумилевскому, префекту Заиконоспасской академии, чье авторство прозаической

45 О его трудах см. Черняев 1906, 164-170.

46 Петров 1818, 120. Любопытно, у какого «родственника» он жил, где доставал тексты древних авторов и с кем советовался? Возможно ли его знакомство с Г. Полетикой, активная переводческая и издательская деятельность которого приходится на это время?

47 См. Лепехин 1999, 188.

48 «Еллиногреческая грамматика» Гумилевского и Протасова, напечатанная тогда же в Москве, оказалась не столь успешной. По «Лащевскому - Щербацкому - Петрову» учились почти полвека, до преобразования гимназий в уварововскую эпоху.

49 Шляпкин 1885, 393. Потемкин цитирует текст издания Дорофея Монемвасийского 1684 г.

50 Брикнер 1891, 72; Лебедев 1876, 217; ср. Гаврилов 2010, 66; возможно, Булгарис сочинил греческую эпитафию Потемкину: там же, 68. 
«Одиссеи» 1788 года, вопреки А.Н.Егунову, не кажется невероятным: ${ }^{51}$ желание и вкус всесильного покровителя ставились выше соображений благочиния, которые, правда, определили анонимность. Раз от разу возобновляет Потемкин чтение греческих классиков «в ослабу утружденна духа», ${ }^{52}$ то есть с напряжением ума, которого эти авторы требуют хотя бы и от гениев. Потемкинские чтения документированы в письме посла Франции Луи де Сегюра, литератора и приятеля фаворита. Дата - 20 декабря 1786 г., накануне легендарного южного путешествия Екатерины. Льстя просветительским исканиям, а равно и учености Потемкина, дипломат сообщает, что с императрицей едет библиотека и что «несколько греческих трагедий и анакреонтических од» он надеется прочесть вместе с князем, а отрывки собирается переложить в стихах. 53

Остается признать небезосновательным тезис Шляпкина, усиленный Егуновым: профессиональный эллинист Петров мог руководить дилетантом Потемкиным в изучении поэм Гомера. Их встречи разнообразно свидетельствуются письмами, одами («мне орли рамена - дар крова твоего» [то есть возможность бывать у тебя $]^{54}$ ) и воспоминаниями. Последним эпистолярным документом дружбы оказывается публикуемое Шляпкиным письмо, где Потемкин уже не Ахиллес, но Александр. (Стоит, впрочем, отметить редкое «градоборец», калькирующее птоліло $\theta$ ос, что использо-

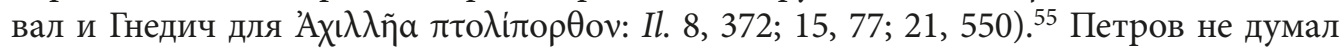
становиться Гомером Потемкина, но великая тень смущала его. Образ Александра на гробнице Ахилла, обыгранный в оде Екатерине («Сердца доброт ей храм, и целый свет - Гомер» ${ }^{56}$ ), и хвала поэтическим способностям своего героя («Когда б он не был Ахиллесом, всемерно был бы он Гомер») - «известный в стихотворстве сочинитель» словно бы отвергает навязываемую ему роль. Он не перевел Гомера, обманув

51 Егунов 2001, 60: «Совершенно невероятно, чтобы перевод Одиссеи был выполнен префектом духовной академии». Прозаический перевод «Одиссеи» 1788 г. числится среди трудов Гумилевского в статье о нем РБС. Префектом он стал в том же году. Ему, кстати, принадлежит и латинский стихотворный подарок Потемкину от имени Славяно-греко-латинской академии (Illustrissimo Comiti Grigorio Alexandridi Potemkin hoc grati animi sui documentum offert Academia Mosquensis). Может быть, именно Гумилевский был также автором некого перевода Пиндара, по заказу Потемкина осуществленного в Москве: о нем упоминает Екатерина в письме Гримму: Грот 1878, 172. Как и Булгарис, Гумилевский был определен Екатериной для духовного руководства вновь приобретенными землями - архиепископом феодосийским и мариупольским.

52 Так в упоминавшейся уже оде Потемкину 1779 года, Петров 1811, Ч. 1, 191: «Чести певца Троянской брани / Был, пишут, Александров вкус: / Как сот, Потемкина гортани / Твой стих, великий отче муз. / В ослабу утружденна духа / Он чтет иль внемлет звон музык; / И судит тонкостию слуха, Чем сладок отчества язык. <..> Не тяжек праздных слов примесом, / Красот во слоге он пример, / Когда б он не был Ахиллесом, всемерно был бы он Гомер».

53 Брикнер 1891, 250-251.

54 Так в оде 1778 года, содержащей уже в начале аллюзию на первую Олимпионику: «...И аки огнь сияет злато, / хотя на свет из мрака взято». Далее поэт по тому же пиндарову образцу сравнивает себя с жаворонком.

55 Самойлов 1867, 999, о победе при Фокшанах: «На случай сей Василий Петрович Петров, известный в стихотворстве сочинитель, сочинил Григорию Александровичу эпистолу, в которой он его уподобил Ахиллесу следующими стихами: “Он жил среди красот и аки Ахиллес, / На ратном поле вдруг он мужество изнес: / Впервый приял он гром, - и гром ему послушен, / Впервыя встретил смерть - и встретил равнодушен!”»

56 Петров 1811, Ч. 3, 256: «На сей когда бы гроб Монархиня взглянула, / Она 6 как Александр отнюдь не воздохнула. / Умы Ее блажат различных стран и вер; / Сердца доброт ей храм, и целый свет - Гомер». 
надежды Потемкина, которые, полагаем, питались и совместными чтениями. Литературный век Петрова, столь сообразный его талантам, умеет намекнуть на заслугу, сохранив почтительность: тем более ясным пониманием «простых» (читай: искренних ${ }^{57}$ ) строк сияла бы улыбка дарителя — «Александра, помняща о Гомере».

\section{Библиография}

Алексеев М.П. Русско-английские литературнье связи (XVIII - первая половина ХІХ века). Москва, Наука, 1982. http://az.lib.ru/m/murawxew_m_n/text_0040.shtml (20.09.2018)

Алексеева Н.Ю. Русская ода. Развитие одической формы в XVII - XVIII веках. Санкт-Петербург, Наука, 2005.

Амелин М. (Изд.) Василий Петров. Оды. Письма в стихах. Разные стихотворения. Выбор Максима Амелина. Вступительная статья М. Амелина. Москва, Б.С.Г.-ПРЕСС, 2016.

Боброва Л.Е., Вацуро В.Э. (Изд., примеч.) И. И. Хемницер. Полное собрание стихотворений. Москва - Ленинград, Советский писатель, 1963.

Брикнер А. Г. Потемкин. Санкт-Петербург, изд. К. Л. Риккера, 1891.

Бурьян Л.К. И.А.Шляпкин и библиотека Саратовского университета. Труды Научной библиотеки при СГУ 1959, 2, 128-133.

Буш В.В. Илья Александрович Шляпкин. Петроград, Типогр. РАН, 1920.

Виницкий И. Синекдохос, в кн. М. Гронас, Б. Шерр (ред.) Лифиии/Лосев/Loceff. Москва, Новое литературное обозрение, 2017, 210-223.

Востриков А.В., Лейбова, А.В., Лейбов К.Г. Библиотека Бестужевских курсов: книжное собрание И. А. Шляпкина, в кн. А. И. Добкин, А. В. Кобак (сост.) Невский архив: Историко-краеведческий сборник. Bып. 2. Москва - Санкт-Петербург, 1995, 398-413.

Гаврилов А. К. О филологах и филологии. Санкт-Петербург, С.-Петербургский гос. университет, 2010. Грот Я. (Изд.) Письма Екатерины II к Гримму (1774-1796). Санкт-Петербург, Типогр. Акад. наук, 1878. Гуковский Г. А. Петров. В кн. Г. А. Гуковский, В. А. Десницкий (ред.) История русской литературы. T. 4. Литература XVIII века. Москва - Ленинград, Изд-во АН СССР, 1947, 353-363.

Дмитириев М.А. Мелочи из запаса моей памяти. Москва, Русский архив, 1869.

Домашнев С.И. Введение [к выпуску]. Академические известия 1779, 1-47.

Дубин А. С. Профессор И. А. Шляпкин - историк и библиофил. Невский библиобил 1999, 4, 178-189.

Егунов А.Н. Гомер в русских переводах XVIII - XIX веков. Москва, Индрик, ${ }^{2} 2001$.

Елисеева О.И. Геополитические проекты Г.А. Потемкина. Москва, Институт Российской истории $\mathrm{PAH}, 2000$.

Зорин А. Кормя двуглавого орла... Литература и государственная идеология в России в последней трети XVIII - первой трети XIX века. Москва, Новое литературное обозрение, 2004.

Йекуч У.Василий Петров и Григорий Потемкин. Об отношениях поэта и покровителя. Russian Literature 2014, 75, 219-248.

Карабанов П.Ф. Исторические рассказы и анекдоты. Гофмейстерины, статс-дамы и фрейлины русского двора XVIII и XIX вв. Ред., примеч. и доп. А. Б. Лобанова-Ростовского (1872). Москва, Государственная публичная историческая библиотека, 2012.

Кочеткова Н.Д. Петров Василий Петрович, в кн.: Н.Д.Кочеткова, Г.Н. Моисеева, А. М.Панченко и др. (Ред.) Словарь русских писателей XVIII века. Санкт-Петербург, Наука, 1999, 425-429.

Кросс А. Г. Василий Петров в Англии $(1772$ - 1774). XVIII век 1976, 11, 229-246.

Кросс А. Г. Стихотворец Василий Петров и его окружение в Лондоне в 1770-е годы, в кн: Н. В. Макарова, О.А.Моргунова (Петрунько) (сост.) Русское присутствие в Британии. Москва, Современная экономика и право, 2009, 181-190.

Лебедев А. Евгений Булгарис, архиепископ Славенский и Херсонский. Древняя и новая Россия 1876, 3, 209-223.

Лепехин М.П. Лащевский, в кн. Д. Кочеткова, Г.Н. Моисеева, А.М.Панченко и др. (Ред.) Словарь русских писателей XVIII века. Санкт-Петербург, Наука, 1999, 188-190.

Медников М.М. И. А.Шляпкин и Псков. Псков 2007, 26, 66-67.

57 Чего не понял П.Н.Полевой, критикующий Петрова за то, что он, «самый напыщенный и манерный из стихотворцев XVIII века, решается говорить о “простоте” как о лучшем украшении поэзии»: Полевой 1900, 111, о «Послании к Екатерине» 1885 года. 
Огарков В. В. Григорий Потемкин. Его жизнь и общественная деятельность. Москва, Директ-Медиа, 2014.

Перетц В.Н. Описание собрания рукописей профессора И.А.Шляпкина, принесенного в дар владельцем Саратовскому государственному университету. Подгот. к печати и ред. В. П. Адрианова-Перетц. Археографический ежегодник за 1959 год. Москва, 1960, 364-466.

Петров В.П. Сочинения. Ч. 1-3. Санкт-Петербург, Медицинская типография, 1811.

Петров Я.В. Жизнь В.П. Петрова. Соревнователь просвещения и благотворения 1818, 1, $116-138$.

Полевой Н. П. История русской словесности. Т. 2. Санкт-Петербург, Типография Маркса, 1900.

Проскурина В. Мифы империи: Литература и власть в эпоху Екатерины II. Москва, Новое литературное обозрение, 2006.

Самойлов А.Н. Жизнь и деяния генерала-фельдмаршала князя Григория Александровича Потемкина Таврического. Русский архив 1867, 4, 575-606; 7, 1-1027.

Серман И.З. В.П. Петров. Биографическая справка, в кн.: Г. П. Макогоненко, И. З. Серман, Н. Д. Кочеткова (Изд., примеч.) Поэты XVIII века. Т.1. Москва - Ленинград, Советский писатель, 1972, 318-325.

Скворцов А. Петров Первый. [Рец. Амелин 2016]. Новый мир 2017, 2. http://magazines.russ.ru/novyi_ mi/2017/2/petrov-pervyj.html (20.10.2018).

Сухомлинов М.И. История российской академии. Вып. 7. Санкт-Петербург, Типогр. Академии наук, 1885.

Топоров В.Н. Из истории русской литературы. Т. ІІ. Москва, Языки славянской культуры, 2007.

Фролов Э. Д. Русская наука об античности (историографические очерки). Санкт-Петербург, Изд-во С. Петерб. ун-та., 1999.

Черняев П.Н. Следь знакомства русского общества с древне-классической литературой в век Екатерины II. Воронеж, Типогр. т-ва Н. Кравцов и К०, 1906.

Шевчук С. В. Федор Богданович Фишер (1782-1854) - первый директор Санкт-Петербургского императорского ботанического сада, в кн.: Т.А.Шрадер (ред.) Немць в Санкт-Петербурге. Биографический аспект. XVIII-XX вв. Bыл. 7. Санкт-Петербург, МАЭ РАН, 2012, 114-129.

Шляпкин И. А. Василий Петрович Петров, «карманный» стихотворец Екатерины II (1736-1799). (По новым данным). Исторический вестник 1885, 23/11, 381-405, сетевая версия И. Ремизова, 2007. http://memoirs.ru/texts/Schl_P_IV85_23_11.htm (30.09.2018).

Шляпкин И. А. Для немногих. Автобиограбическая заметка проф. И. А. Шляпкина. Санкт-Петербург, Тип. Мартынова, 1907.

Martynov I. F. Notes on V.P. Petrov and his stay in England: (New materials). Study Group of Eighteenth Century Russia. Newsletter. 1979, 7, 29-31.

Pfeiffer R. Geschichte der klassischen Philologie. Von den Anfängen bis zum Ende des Hellenismus. Aus dem Englischen übertragen von M. Arnold. München, Beck, ${ }^{2} 1978$.

\section{References}

Alekseev M.P. Russko-angliiskie literaturnye sviazi (XVIII - pervaia polovina XIX veka) [Russian-English literary connections. $18^{\text {th }}$ - first half of the $19^{\text {th }} \mathrm{c}$.] Moscow, Nauka, 1982. (In Russian)

Alekseeva N. Iu. Russkaia oda. Razvitie odicheskoi formy v XVII - XVIII vekah [Russian ode. The development of odic form in $17^{\text {th }}-18^{\text {th }} \mathrm{c}$.] Saint Petersburg, Science, 2005. (In Russian)

Amelin M. (ed., introd.) Vassili Petrov. Ody, Pisma v stihah, raznye stihotvoreniia [Odes, Epistles, Various poems]. Moscow, B.S.G.-PRESS, 2016. (In Russian)

Bobrova L.E., Vatsuro V.E.(eds, comm.) I.I. Khemnitser. Polnoe sobranie stihotvorenii [Complete poems]. Moscow - Leningrad, Sovetskii pisatel, 1963. (In Russian)

Brikner A. G. Potemkin. Saint Petersburg, K. L. Rikker, 1891. (In Russian)

Burian L. K. I. A. Shliapkin i biblioteka Saratovskogo Universiteta [I. A. Shliapkin and the library of Saratov University]. Trudy nauchnoi biblioteki pri SGU. 1959, 2, 128-133. (In Russian)

Bush V. V. Ilia Aleksandrovich Shiapkin. Petrograd, Tipogr. RAN, 1920. (In Russian)

Cherniaev P. N. Sledy znakomstva russkogo obshchestva s drevne-klassicheskoi literaturoi v vek Ekateriny II [Traces of Russian society's acquaintance with ancient classical culture in the age of Catherine II]. Voronezh, Kravtsov, 1906. (In Russian) 
Cross A. Vasilii Petrov in England (1772-1774). XVIII vek 11976, 11, 229-246. (In Russian)

Cross A. Stikhotvorets Vasilii Petrov I ego okruzhenie v Londone [Poet Vasilii Petrov and his surrounding in London in 1770ies], in: N. V. Makarova, O. A. Morgunova (eds). Russian Presence in Britain. Moscow, Sovremennaia ekonomika i pravo, 2009. (In Russian)

Dmitriev M. A. Melochi iz zapasa moei pamiati [Trifles from a stock of my memory]. Moscow, Russian Archive, 1869. (In Russian)

Domashnev S. I. Vvedenie k vypusku [Introduction to the issue]. Akademicheskie iyvestiia 1779, 1-4. (In Russian)

Dubin A.S. Professor I. A. Shliapkin - istorik i bibliofil [Professor I. A. Shliapkin - historian and bibliophile]. Nevskii bibliofil 1999, 4, 178-189. (In Russian)

Egunov A. N. Gomer v russkikh perevodakh XVIII - XIX v. [Homer in Russian translations of $18^{\text {th }}-19^{\text {th }} \mathrm{c}$.] Moscow, Indrik, ${ }^{2} 2001$. (In Russian)

Eliseeva O. I. Geopoliticheskie proekty G. A. Potemkina [Geopolitical projects of G. A. Potemkin]. Moscow, Institute of Russian history, 2000. (In Russian)

Frolov E. D. Russkaia Nauka ob Antichnosti: Istoriograficheskie Ocherki [Russian science on Antiquity: Historiographical essays]. Saint Petersburg, SPbGU, 1999. (In Russian)

Gavrilov A.K. O philologakh i philologii [On philologists and philology]. Saint Petersburg, SPbGU, 2010. (In Russian)

Golburt L. Vasilii Petrov and the Poetics of Patronage. Вивліоөика: E-Journal of Eighteenth-Century Russian Studies. 2015, 3, 47-69.

Grot Ia. (ed.) Pis'ma Ekateriny II k Grimmu [Letters of Catherine II to Grimm] (1774-1796). Saint Petersburg, Akademia Nauk, 1878. (In Russian)

Gukovskii G. A. Petrov, in: Gukovskii G. A. et al. (eds). Istoriia russkoi literatury [History of Russian Literature]. Moscow - Saint Petersburg, Akademia Nauk, 1947. (In Russian)

Jekutsch U. Ob otnosheniiakh poeta i pokrovitelia [Vasilii Petrov and Grigorii A. Potemkin: On the Relations between Poet and Patron]. Russian Literature 2014, 75, 219-248. (In Russian)

Karabanov P. F. Istoricheskie rasskazy $i$ anekdoty. Gofmeysteriny, stats-damy i freyliny russkogo dvora XVIII $i$ XIX vv. [Historical stories and anecdotes. Chief maids of honor, ladies-in-waiting and maids of honor of the Russian imperial court $18^{\text {th }}$ and $19^{\text {th }}$ c.] Ed., comm. A. B. Lobanov-Rostovskii (1872). Moscow, Gusudarstvennaia publichnaia istoricheskaia biblioteka, 2012. (In Russian)

Kochetkova N. D. Petrov Vasilii Petrovich, in: N. D. Kochetkova et al. Slovar russkih pisalelei XVIII veka [Dictionary of Russian writers of the $18^{\text {th }}$ c.] Saint Petersburg, Nauka, 1999, 425-429. (In Russian)

Martynov I. F. Notes on V.P.Petrov and his stay in England: (New materials). Study Group of Eighteenth Century Russia. Newsletter. 1979, 7, 29-31.

Mednikov M. M. I. A. Shliapkin i Pskov [I. A. Shiapkin and Pskov]. Pskov 2007, 26, 66-67. (In Russian)

Lebedev A. Evgenii Bulgaris, arkhiepiskop Slavenskii I Khersonskii [Eugenios Bulgaris, Archbishop of Slaviansk and Kherson] Drevniaia I novaia Rossiia 1876, 3, 209-223. (In Russian)

Lepekhin M. P. Laschevski, in: N. D. Kochetkova et al. Slovar russkih pisalelei XVIII veka [Dictionary of Russian writers of the $18^{\text {th }}$ c.] Saint Petersburg, Nauka, 1999, 188-190. (In Russian)

Ogarkov V. V. Grigorii Potemkin. Ego zhizn' i obschestvennaia deiatel'nost'. [His life and political activities]. Moscow, Direct-Media, 22014. (In Russian)

Perets V.N. Opisaniie sobraniia rukopisei professora I. A. Shliapkina, prinesennogo v dar vladeltsem Saratovskomu gosudarstvennomu universitetu. [Description of the manuscript collection of brofessor I. A. Shliapkin presented by the owner to Saratov State University.] Ed. V.P. Adrianova-Perets. Archeograficheskii ezhegodnik for 1959. Moscow, 1960. 364-466. (In Russian)

Petrov V.P. Sochineniia [Complete works]. Saint Peterburg, Meditsinskaia tipografiia, 1811.

Petrov Ia. V. Zhizn' V.P. Petrova [Life of V.P. Petrov]. Sorevnovatel' prosvescheniia I blagotvoreniia 1818, 1, 116-138. (In Russian)

Polevoi N. P. Istoriia russkoi slovesnosti [History of Russian literatue] T. 2. Saint Petersburg, Marx, 1900.

Proskurina V. Mify imperii. Literatura i vlast'v epokhu Ekateriny II [Myths of Empire. Literature and Power in time of Catherine II]. Moscow, NLO, 2006. (In Russian)

Pfeiffer R. Geschichte der klassischen Philologie. Von den Anfängen bis zum Ende des Hellenismus. Aus dem Englischen übertragen von M. Arnold. München, Beck, ${ }^{2} 1978$.

Samoilov A.N. Zhiyn' i deianiia generala-feldmarshala kniazia Grigoriia Aleksandrovicha Potemkina Tavricheskogo [Life and work of general-field marshal prince Grigori Alexandrovich Potemkin-Tavricheski]. Russkii arkhiv 1867, 4, 575-606; 7, 1-1027. (In Russian) 
Serman I.Z. V.P. Petrov. Biorgaficheskaia spravka [Biographical reference], in: G. P. Makogonenko et al. (eds) Poety XVIII veka [Poets of the $18^{\text {th }}$ c.] T. 1. Moscow - Leningrad, Sovetskii pisatel, 1972. (In Russian)

Shevchuk S. V. Fedor Bogdanovich Fisher, in: T.Schrader (red.) Nemtsy $v$ Sankt Peterburge. [Germans in St. Petersburg] 7, SPb., MAE RAN, 2012, 114-129. (In Russian)

Shliapkin I.A. Dlia nemnogih. Autobiograficheskaya zametka prof. I. A. Shliapkina [For the few. Autobiographical note of prof. I. A. Shliapkin]. SPb., Tip. Martynova, 1907. (In Russian)

Shliapkin I. A. Vasili Petrovich Petrov - "karmannyi" stikhotvorets Ekateriny II. (1736-1799). (Po novym dannym). [V.P. Petrov - "pocket" poet of Catherine II (based on new materials)]. Istoricheskii vestnik 1885, 23/11, 381-405. (In Russian)

Skvortsov A. Petrov Pervyi [Petrov the first. Rec. Amelin 2016] Novyi mir 2017, 2, http://magazines.russ.ru/ novyi_mi/2017/2/petrov-pervyj.html (20.10.2018). (In Russian)

Soisson J.-P. Jacques Amyot (1513-1593). Paris, Éd. France-Empire Monde, 2013.

Toporov V.N. Iz istorii risskoi literatury [From the history of Russian literature]. Moscow, Iazyki slavianskoi kultury] 2007. (In Russian)

Sukhomlinov M. I. Istoriia rossiiskoi akademii [Hiostory of Russian Academy] 7. Saint Petersburg, Academy of science, 1885. (In Russian)

Vinitskii I. Synekdochos, in: M. Gronas, B. Sherr (eds) Lifshits/Losev/Loseff. Moskow, NLO, 2017, 210-223.

Vostrikov et al. Biblioteka Bestuzhevskih Kursov: knizhnoe sobranie I. A. Shliapkina [Library of Bestuzhev Courses: I. A. Shliapkin's book collection], in: I. A. Dobkin et al. (eds) Nevski Archive 2. Moscow Saint Petersburg, 1995, 398-413. (In Russian)

Zorin A. Kormia dvuglavogo orla... Literatura i gosudarstvennaia ideologiia v Rossii v poslednei treti XVIII pervoi treti XIX veka. [Nourishing the Double-Headed Eagle... Literature and State Ideology in Russia in the Last Third of the Eighteenth - First Third of the Nineteenth Century]. Moskow, Novoe literaturnoe obozrenie, 2004. (In Russian)

Received: August 19, 2018

Accepted: October 20, 2018

\section{Potemkin's Homer}

\section{Mikhail M. Pozdnev}

St. Petersburg State University,

7-9, Universitetskaya nab., St. Petersburg, 199034, Russian Federation; m.pozdnev@spbu.ru

Vassily Petrov (1736-1799) rose from obscurity to become a poet laureate, librarian and private reader to Catherine the Great through his knowledge of the Classical literature and feeling for poetic convention. Aiming high and talented (he translated the Aeneis), he was able to set any event of recent history in the marble of a Pindaric ode producing pieces meant for eternity, but saw them crumble shortly after Catherine's death. On evidence of misquoting, Petrov's biographers claim that he owed his rise to Grigory Potemkin (1739-1791), who was his peer back in Moscow. While viewed at a distance (which tends to blur chronology) Potemkin will ever be the conqueror for the Crown and the man in the life of the Empress, it was Petrov who actually helped the future favorite to work his way up. They went unacquainted as peers, and their friendship is due, in large part, to Potemkin's interest in ancient authors which Petrov could comment on. The letter quoted by Petrov's late $19^{\text {th }}$ century biographer I. A. Shliapkin in support of his vainglorious pretensions proves the opposite: gracefully thanking his victorious friend, Petrov goes on to praise his passion for Classics: "The hand that smote the Turks now solaces me with friendly lines! I see the Great Alexander amongst the din of victorious battle mindful of Homer". The untrained eye saw Petrov brazen enough to go around calling himself Homer, while the trite allusion was made to the Ilias compiled by Aristotle to follow Alexander in his deeds of valour. Potemkin and Catherine expected Petrov to deliver the first Russian translation of Homer which the poet probably had planned but never accomplished. Keywords: Vassily Petrov, Russian translators of Homer, Grigory Potemkin. 